\title{
Effects of Nitrogen Application on Growth and Ethanol Yield of Sweet Sorghum [Sorghum bicolor (L.) Moench] Varieties
}

\author{
Oluwatoyin Olugbemi ${ }^{1}$ and Yekeen Abiola Ababyomi ${ }^{2}$ \\ ${ }^{1}$ Energy Commission of Nigeria, PMB 358, Garki, Abuja, Federal Capital Territory, Nigeria \\ ${ }^{2}$ Department of Agronomy, University of Ilorin, PMB 1515, Ilorin, Kwara State, Nigeria \\ Correspondence should be addressed to Oluwatoyin Olugbemi; t.olugbemi@yahoo.com
}

Received 3 June 2016; Accepted 18 August 2016

Academic Editor: Fachuang Lu

Copyright @ 2016 O. Olugbemi and Y. Abiola Ababyomi. This is an open access article distributed under the Creative Commons Attribution License, which permits unrestricted use, distribution, and reproduction in any medium, provided the original work is properly cited.

\begin{abstract}
A study was carried out in two locations, Ilorin ( $8^{\circ} 29^{\prime} \mathrm{N} ; 4^{\circ} 35^{\prime} \mathrm{E}$; about $310 \mathrm{~m}$ asl $)$ and Ejiba $\left(8^{\circ} 17^{\prime} \mathrm{N} ; 5^{\circ} 39^{\prime} \mathrm{E}\right.$; about $246 \mathrm{~m}$ asl), at the Southern Guinea Savannah agroecological zone of Nigeria to assess the effect of nitrogen fertilizer on the growth and ethanol yield of four sweet sorghum varieties (NTJ-2, 64 DTN, SW Makarfi 2006, and SW Dansadau 2007). Five N fertilizer levels (0, 40, 80,120 , and $160 \mathrm{~kg} \mathrm{ha}^{-1}$ ) were used in a $4 \times 5$ factorial experiment, laid out in split-plots arrangement. The application of nitrogen fertilizer was shown to enhance the growth of sweet sorghum as observed in the plant height, LAI, CGR, and other growth indices. Nitrogen fertilizer application also enhanced the ethanol yield of the crop, as variations in growth parameters and ethanol yield were observed among the four varieties studied. The variety SW Dansadau 2007 was observed as the most promising in terms of growth and ethanol yield, and the application of $120 \mathrm{~kg} \mathrm{~N} \mathrm{ha}^{-1}$ resulted in the best ethanol yield at the study area.
\end{abstract}

\section{Introduction}

The quest for alternative energy sources in the wake of environmental problems created as a result of overdependence on conventional energy sources has led to an increase in research in the field of renewable energy sources such as biofuels which include biodiesel and bioethanol [1-3]. Biodiesel is obtained from plants that are rich in oil while bioethanol is obtained from plants that are rich in fermentable sugar or other carbohydrates which can further be broken down to fermentable sugars. The major commercial sources of bioethanol include sugarcane, sugar beets, and corn. Sweet sorghum is also recently gaining popularity as a major feedstock for commercial bioethanol production because of its numerous advantages which include high fermentable sugar, early maturity, and low nutrient and water requirements $[4$, 5].

Sweet sorghum is an annual energy crop that favourably answers the "food or fuel" question as it does not compete with food or feed, and it can ratoon, following harvest, under favourable climatic conditions. These features have made sweet sorghum a choice bioethanol crop of the semiarid tropics in the sub-Saharan Africa and India [6]. It is a crop of high universal value since it can be cultivated in tropical, subtropical, temperate, and semiarid regions, as well as in poor quality soils of the world [7]. It is termed "the sugarcane of the desert" or "the camel among crops" due to its drought hardy characteristics [8].

The biomass yields of sweet sorghum have been reported to vary across a range of nitrogen $(\mathrm{N})$ fertilizer rates, cultivars, and plant populations. For instance, Wortmann et al. [9] reported dry stalk yields from 8 to 48 metric ton ha ${ }^{-1}$ across a range of $\mathrm{N}$ fertilization rates, cultivars, and plant populations. Soileau and Bradford [10] measured dry biomass yields ranging from 6 to 18 metric ton $\mathrm{ha}^{-1}$ across a range of fertilization and liming treatments. Other workers such as Reddy et al. [11], Turgut et al. [12], and Uchino et al. [13] have carried out studies on the optimization of nitrogen requirements of sweet sorghum for various environments and soil types. There is, however, very little or no information available in this part of the world on the effect of $\mathrm{N}$ fertilizer on the growth and especially the ethanol yield of sweet sorghum. 
This is because attention is devoted more to cultivating both grain and sweet sorghum types for their grains, and there is very low level of awareness on the usefulness of the crop for biofuel production. In order for sweet sorghum to be a sustainable energy crop, there is a need to not only breed high yielding varieties, but also develop and establish appropriate agronomic practices, including the use of optimum level of $\mathrm{N}$ fertilizer. This study was therefore carried out to assess the effect of nitrogen fertilizer application on the growth and ethanol yield of sweet sorghum varieties in the Southern Guinea Savannah agroecological zone of Nigeria.

\section{Materials and Methods}

A study was conducted during the 2015 cropping season at the University of Ilorin Teaching and Research farm, Ilorin (latitude $8^{\circ} 29^{\prime} \mathrm{N}$, longitude $4^{\circ} 35^{\prime} \mathrm{E}$; about $310 \mathrm{~m}$ above sea level), and Lower Niger River Development Authority (LNRDA) farm, Ejiba (latitude $8^{\circ} 17^{\prime} \mathrm{N}$, longitude $5^{\circ} 39^{\prime} \mathrm{E}$; about $246 \mathrm{~m}$ above sea level). The two sites fall within the Southern Guinea Savannah agroecological zone of Nigeria. The fields in both sites were cleared, ploughed, harrowed, and ridged. The field was thereafter divided into plots, each made up of 4 ridges of $3 \mathrm{~m}$ long with interrow spacing of $1 \mathrm{~m}$, representing an area of $12 \mathrm{~m}^{2}$. The experiment was a 4 $\times 5$ factorial in a randomised complete block design, laid out in split-plot arrangement, and replicated three times. Four sweet sorghum varieties (NTJ-2, 64 DTN, SW Makarfi 2006, and SW Dansadau 2007), obtained from the Institute of Agricultural Research (IAR), Ahmadu Bello University (ABU), Zaria, Nigeria, were allotted to the main plots while nitrogen fertilizer levels $\left(0,40,80,120\right.$, and $\left.160 \mathrm{~kg} \mathrm{ha}^{-1}\right)$ were allotted to the subplot.

The seeds were sown directly on the ridges on 8 and 30 June 2015 at the Ilorin and Ejiba sites, respectively, with an intrarow spacing of $0.25 \mathrm{~m}$. The seedlings were later thinned to two plants per stand. The plots were sprayed immediately after sowing with atrazine $\left(500 \mathrm{~g} \mathrm{~L}^{-1}\right.$ ai) at the rate of $5 \mathrm{~L} \mathrm{ha}^{-1}$. This was then supplemented with hoeing at eight weeks after sowing (WAS). Nitrogen fertilizer was applied in two equal doses according to the treatment. The first dose of nitrogen fertilizer was applied immediately after thinning ( 3 WAS), in addition to $40 \mathrm{~kg} \mathrm{ha}^{-1}$ of phosphorus $\left(\mathrm{P}_{2} \mathrm{O}_{5}\right)$ and potassium $\left(\mathrm{K}_{2} \mathrm{O}\right)$ which were applied to all the plots. The second dose was applied at 8 weeks after planting, immediately after hoeing. For the first dose, NPK 20:10:10 compound fertilizer was used for the plots receiving nitrogen fertilization; the $\mathrm{P}_{2} \mathrm{O}_{5}$ and $\mathrm{K}_{2} \mathrm{O}$ were supplemented using single super phosphate (SSP) and muriate of potash (MOP), respectively, to make up the required $40 \mathrm{~kg} \mathrm{ha}^{-1}$. For the plots without nitrogen fertilization, only SSP and MOP were applied. Urea was used for the second dose and applied to each plot according to the required treatments. Preplanting soil samples of the top soil $(0-30 \mathrm{~cm})$ were obtained for physical and chemical analysis.

Plant height of five randomly selected plants from the inner rows of each plot were measured biweekly beginning from 4 to 10 WAS. Leaf area per plant and dry matter
TABLE 1: Soil physicochemical characteristics of Ilorin and Ejiba experimental sites.

\begin{tabular}{lcc}
\hline Parameter & Ilorin & Ejiba \\
\hline $\mathrm{pH}$ & 6.20 & 6.70 \\
Total N (\%) & 0.16 & 0.18 \\
Available P $\left(\mathrm{mg} \mathrm{kg}^{-1}\right)$ & 4.51 & 4.20 \\
Exchangeable $\mathrm{K}(\mathrm{cmol})$ & 0.52 & 1.90 \\
Exchangeable $\mathrm{Ca}(\mathrm{cmol})$ & 1.12 & 0.32 \\
Exchangeable $\mathrm{Mg}(\mathrm{cmol})$ & 0.81 & 0.14 \\
Exchangeable $\mathrm{Na}(\mathrm{cmol})$ & 0.28 & 0.82 \\
Exchangeable $\mathrm{H}^{+}+\mathrm{Al}(\mathrm{cmol})$ & 0.21 & 0.20 \\
ECEC (cmol) & 2.94 & 3.38 \\
Organic carbon $(\%)$ & 1.43 & 0.30 \\
Sand $(\%)$ & 85.52 & 86.40 \\
Silt $(\%)$ & 6.00 & 6.00 \\
Clay $(\%)$ & 8.48 & 7.60 \\
Textural class & \multicolumn{2}{c}{ Loamy sand } \\
\hline
\end{tabular}

yield were obtained at 6 and 10 WAS from the product of the length and breadth of each leaf and a factor of 0.75 according to Stickler et al. [14] and Moll and Kamprath [15]. Growth indices such as leaf area index (LAI), crop growth rate (CGR), relative growth rate (RGR), leaf area ratio (LAR), and net assimilation rate (NAR) were calculated from the leaf area and the dry matter yield according to Hunt [16]. Yield parameters obtained include fresh stalk yield, dry stalk yield, stalk girth, and stalk length. The brix was measured using a handheld refractometer (Bellingham \& Stanley Ltd., Tunbridge Wells, UK). The theoretical juice yield $\left(\mathrm{tha}^{-1}\right)$ and sugar yield $\left(\mathrm{tha}^{-1}\right)$ of the stalks were then calculated according to Tew et al. [17] and Wortmann et al. [9] in the following steps:

$$
\begin{aligned}
\text { CSY } & =(\text { FSY }- \text { DSY }) \times\left(\frac{\text { Brix }}{100}\right) \times 0.75, \\
\text { JY, 80\% extracted } & =[\text { FSY }-(\text { DSY }- \text { CSY })] \times 0.8, \\
\text { SY } & =\mathrm{JY} \times\left(\frac{\text { Brix }}{100}\right) \times 0.75,
\end{aligned}
$$

where CSY is the conservative sugar yield $\left(\right.$ g plant $^{-1}$ ), FSY is fresh stalk yield (g plant ${ }^{-1}$ ), DSY is dry stalk yield $\left(\right.$ g plant $^{-1}$ ), JY is juice yield $\left(\right.$ g plant $^{-1}$ ) with $80 \%$ extraction efficiency assumed, and SY is sugar yield (g plant ${ }^{-1}$ ). The sugar concentration of juice was assumed to be $75 \%$ of brix value. Ethanol yield was then estimated as a product of sugar yield and a factor, $0.581[9,18-20]$.

All data obtained were subjected to analysis of variance using Genstat Discovery 4 statistical package and the means separated using the least significant difference (LSD) at 5\% probability level.

\section{Results and Discussion}

The results of the physicochemical analysis (Table 1) show that the soil of the two sites of the study could be classified as 
TABLE 2: Main effects of variety and $N$ fertilizer on the plant heights $(\mathrm{cm})$ of sweet sorghum at 4 to 10 weeks after sowing (WAS) at the Ilorin (ILR) and Ejiba (EJB) experimental sites.

\begin{tabular}{|c|c|c|c|c|c|c|c|c|}
\hline \multirow{2}{*}{ Treatment } & \multicolumn{2}{|c|}{4} & \multicolumn{2}{|c|}{6} & \multicolumn{2}{|c|}{8} & \multicolumn{2}{|c|}{10} \\
\hline & ILR & EJB & ILR & EJB & ILR & EJB & ILR & EJB \\
\hline \multicolumn{9}{|l|}{ Variety $(V)$} \\
\hline NTJ-2 & 38.89 & $28.71^{\mathrm{a}}$ & $55.33^{\mathrm{b}}$ & $54.22^{\mathrm{c}}$ & $103.55^{\mathrm{b}}$ & $104.78^{\mathrm{bc}}$ & $146.83^{\mathrm{b}}$ & $155.11^{\mathrm{b}}$ \\
\hline $64 \mathrm{DTN}$ & 33.25 & $25.65^{\mathrm{b}}$ & $48.05^{\mathrm{c}}$ & $55.71^{\mathrm{c}}$ & $97.56^{\mathrm{b}}$ & $101.68^{\mathrm{c}}$ & $139.51^{\mathrm{b}}$ & $145.74^{\mathrm{b}}$ \\
\hline SW Makarfi 2006 & 37.42 & $24.41^{\mathrm{b}}$ & $62.17^{\mathrm{a}}$ & $63.34^{\mathrm{b}}$ & $129.35^{\mathrm{a}}$ & $114.47^{\mathrm{b}}$ & $168.54^{\mathrm{a}}$ & $168.91^{\mathrm{a}}$ \\
\hline SW Dansadau 2007 & 38.30 & $28.63^{\mathrm{a}}$ & $59.97^{\mathrm{ab}}$ & $69.58^{\mathrm{a}}$ & $127.01^{\mathrm{a}}$ & $132.07^{\mathrm{a}}$ & $177.17^{\mathrm{a}}$ & $177.61^{\mathrm{a}}$ \\
\hline SED & 3.211 & 0.916 & 2.942 & 1.748 & 4.366 & 5.207 & 3.753 & 5.630 \\
\hline $\operatorname{LSD}_{(0.05)}$ & ns & 2.240 & 7.200 & 4.276 & 10.683 & 12.742 & 9.184 & 13.775 \\
\hline \multicolumn{9}{|c|}{ Fertilizer (F) $\left(\mathrm{kgNha}^{-1}\right)$} \\
\hline 0 & 34.10 & 25.64 & $48.68^{\mathrm{c}}$ & $48.46^{\mathrm{b}}$ & $84.98^{\mathrm{c}}$ & $93.03^{\mathrm{b}}$ & $127.04^{\mathrm{b}}$ & $122.74^{\mathrm{c}}$ \\
\hline 40 & 38.17 & 26.01 & $60.53^{\mathrm{a}}$ & $63.70^{\mathrm{a}}$ & $116.62^{c}$ & $123.96^{\mathrm{a}}$ & $161.26^{\mathrm{a}}$ & $169.90^{\mathrm{ab}}$ \\
\hline 80 & 36.60 & 28.74 & $53.21^{\mathrm{bc}}$ & $66.48^{\mathrm{a}}$ & $119.75^{\mathrm{ab}}$ & $117.57^{\mathrm{a}}$ & $165.83^{\mathrm{a}}$ & $170.48^{\mathrm{ab}}$ \\
\hline 120 & 36.08 & 27.93 & $58.91^{\mathrm{ab}}$ & $64.86^{\mathrm{a}}$ & $122.47^{\mathrm{ab}}$ & $120.93^{\mathrm{a}}$ & $167.75^{\mathrm{a}}$ & $182.17^{\mathrm{a}}$ \\
\hline 160 & 39.86 & 25.93 & $60.56^{\mathrm{a}}$ & $60.05^{\mathrm{a}}$ & $128.02^{\mathrm{a}}$ & $110.76^{\mathrm{a}}$ & $168.19^{\mathrm{a}}$ & $163.92^{\mathrm{b}}$ \\
\hline SED & 2.206 & 1.807 & 2.970 & 3.701 & 4.709 & 6.958 & 5.306 & 8.791 \\
\hline $\operatorname{LSD}_{(0.05)}$ & ns & ns & 6.049 & 7.539 & 9.592 & 14.172 & 10.807 & 17.906 \\
\hline \multicolumn{9}{|l|}{ Interaction } \\
\hline $\mathrm{V} \times \mathrm{F}$ & ns & $\mathrm{ns}$ & ns & ns & $*$ & $*$ & ns & ns \\
\hline
\end{tabular}

Means followed by the same letters are not significantly different from each other at $5 \%$ probability level. $\operatorname{LSD}_{(0.05)}$ : least significant difference at $5 \%$ probability level. SED: standard error of difference. * denotes significance at 5\% probability level. ns: not significant.

loamy sand. The soil $\mathrm{pH}$, being slightly acidic (6.2 and 6.7 for the two sites, resp.), falls within the wide range of $\mathrm{pH}(5.0-8.5)$ that can be tolerated by the crop $[21,22]$. The total nitrogen obtained for the soil samples falls within the moderately low range at the two sites, making the sites appropriate for the study. Available phosphorus can be considered low in the soil samples of the experimental sites while exchangeable potassium values could be categorized as moderate.

Significant differences were observed in the heights of the sweet sorghum varieties studied, especially towards the end of the measurement period (i.e., 10 WAS), with the variety SW Dansadau 2007 being significantly taller than NTJ-2 and 64 DTN but having similar heights to SW Makarfi 2006 at both sites of the study (Table 2). This observation is in agreement with those of earlier studies where significant variations were reported in the heights of sweet sorghum varieties [23$25]$. The effect of nitrogen fertilizer on the height of sweet sorghum became apparent from 6 WAS. At 10 WAS in Ilorin, significant difference did not exist in the heights produced by the application of the rates of 40 to $160 \mathrm{~kg} \mathrm{~N} \mathrm{ha}^{-1}$, although the heights differ significantly from that of the control. Similar results were also obtained at the Ejiba site, where, however, $160 \mathrm{~kg} \mathrm{~N} \mathrm{ha}^{-1}$ fertilizer rate resulted in shorter plant than the application of $120 \mathrm{~kg} \mathrm{~N} \mathrm{ha}^{-1}$. The trends of response observed were similar to the observations of Uchino et al. [13] who reported that plant height increased with increased nitrogen fertilizer level. The interactive effect of variety $\times \mathrm{N}$ fertilizer observed at 8 WAS in both sites points to the fact that there were variations in the responses of the varieties to the application of $\mathrm{N}$ fertilizer.
At the Ilorin experimental site, no significant difference was observed among the varieties in the growth indices, except LAI where the highest value was recorded for the variety 64 DTN (Table 3(a)). At the Ejiba experimental site, NTJ-2 had the highest LAI but the value did not differ significantly from that of 64 DTN and SW Dansadau 2007 (Table 3(b)). Apart from LAI, significant differences were observed in the LAR and NAR of the varieties at the Ejiba site. The highest LAR was observed in 64 DTN and the highest NAR was observed in SW Makarfi 2006. LAI was observed to increase with increase in nitrogen fertilizer application at the Ilorin site, with the highest LAI obtained with the application of $160 \mathrm{~kg} \mathrm{ha}^{-1}$. Singh et al. [26] reported an increase in the leaf area index of sweet sorghum with increase in $\mathrm{N}$ fertilizer application. The trend of LAI in response to $\mathrm{N}$ fertilizer at the Ejiba site was slightly different, where 40,80 , and $120 \mathrm{~kg} \mathrm{~N} \mathrm{ha}^{-1}$ resulted in similar LAI. This could be as a result of higher native $\mathrm{N}$ in Ejiba. The highest LAR was observed in the control, and the least with the application of $120 \mathrm{~kg} \mathrm{~N} \mathrm{ha}^{-1}$ at the Ilorin site. Similar results have been reported for maize in which LAR value was higher in the control $\left(0 \mathrm{~kg} \mathrm{Nha}^{-1}\right)$ than with the application of $\mathrm{N}$ fertilizer [27]. Nitrogen fertilizer application did affect the LAR significantly at the Ejiba site. The highest NAR and CGR values were obtained with the application of $120 \mathrm{~kg} \mathrm{Nha}^{-1}$ at the Ilorin site, while the highest values for these indices were obtained with the application of $40 \mathrm{~kg} \mathrm{Nha}^{-1}$ at the Ejiba site. No significant effect of $\mathrm{N}$ application on RGR was observed at both sites. 
TABLE 3: (a) Main effects of variety and $\mathrm{N}$ fertilizer on the leaf area index (LAI), leaf area ratio (LAR, $\mathrm{cm}^{2} \mathrm{~g}^{-1}$ ), net assimilation rate (NAR, $\left.\mathrm{g} \mathrm{m}^{-2} \mathrm{day}^{-1}\right)$, relative growth rate (RGR, $\left.\mathrm{g} \mathrm{g}^{-1} \mathrm{day}^{-1}\right)$, and crop growth rate $\left(\mathrm{CGR}, \mathrm{g} \mathrm{m}^{-2}\right.$ day ${ }^{-1}$ ) of sweet sorghum at the Ilorin experimental site. (b) Main effects of variety and $\mathrm{N}$ fertilizer on the leaf area index (LAI), leaf area ratio (LAR, $\mathrm{cm}^{2} \mathrm{~g}^{-1}$ ), net assimilation rate (NAR, $\mathrm{g} \mathrm{m}^{-2}$ day $^{-1}$ ), relative growth rate (RGR, $\mathrm{g} \mathrm{g}^{-1} \mathrm{day}^{-1}$ ), and crop growth rate (CGR, $\mathrm{g} \mathrm{m}^{-2}$ day $^{-1}$ ) of sweet sorghum at the Ejiba experimental site.

(a)

\begin{tabular}{|c|c|c|c|c|c|}
\hline Treatment & LAI & LAR & NAR & RGR & CGR \\
\hline \multicolumn{6}{|l|}{$\operatorname{Variety}(V)$} \\
\hline NTJ-2 & $2.31^{\mathrm{b}}$ & 169.4 & 7.26 & 0.088 & 14.24 \\
\hline 64 DTN & $2.51^{\mathrm{a}}$ & 168.6 & 7.45 & 0.089 & 15.69 \\
\hline SW Makarfi 2006 & $1.96^{\mathrm{c}}$ & 151.2 & 7.69 & 0.079 & 13.88 \\
\hline SW Dansadau 2007 & $2.21^{\mathrm{b}}$ & 150.6 & 8.05 & 0.083 & 16.26 \\
\hline SED & 0.064 & 7.54 & 0.514 & 0.006 & 0.818 \\
\hline $\operatorname{LSD}_{(0.05)}$ & 0.158 & ns & ns & ns & ns \\
\hline \multicolumn{6}{|c|}{ Fertilizer $(F)\left(\mathrm{kgNha}^{-1}\right)$} \\
\hline 0 & $1.53^{c}$ & $179.8^{\mathrm{a}}$ & $6.36^{\mathrm{d}}$ & 0.083 & $8.36^{\mathrm{c}}$ \\
\hline 40 & $2.28^{\mathrm{b}}$ & $160.3^{\mathrm{b}}$ & $7.43^{\mathrm{bc}}$ & 0.082 & $14.84^{\mathrm{b}}$ \\
\hline 80 & $2.11^{\mathrm{b}}$ & $163.3^{\mathrm{b}}$ & $6.81^{\mathrm{cd}}$ & 0.080 & $12.72^{\mathrm{b}}$ \\
\hline 120 & $2.61^{\mathrm{a}}$ & $143.9^{c}$ & $9.02^{\mathrm{a}}$ & 0.090 & $19.79^{\mathrm{a}}$ \\
\hline 160 & $2.71^{\mathrm{a}}$ & $152.4^{\mathrm{bc}}$ & $8.43^{\mathrm{ab}}$ & 0.088 & $19.37^{\mathrm{a}}$ \\
\hline SED & 0.127 & 6.15 & 0.514 & 4.516 & 1.148 \\
\hline $\operatorname{LSD}_{(0.05)}$ & 0.259 & 12.52 & 1.047 & ns & 2.339 \\
\hline \multicolumn{6}{|l|}{ Interaction } \\
\hline $\mathrm{V} \times \mathrm{F}$ & $* *$ & ns & ns & ns & $* *$ \\
\hline
\end{tabular}

Means followed by the same letters are not significantly different from each other at $5 \%$ probability level. $\mathrm{LSD}_{(0.05)}$ : least significant difference at $5 \%$ probability level. SED: standard error of difference. $* *$ denotes significance at $1 \%$ probability level. ns: not significant.

(b)

\begin{tabular}{|c|c|c|c|c|c|}
\hline Treatment & LAI & LAR & NAR & RGR & CGR \\
\hline \multicolumn{6}{|l|}{$\operatorname{Variety}(V)$} \\
\hline NTJ-2 & $1.96^{\mathrm{a}}$ & $146.9^{\mathrm{b}}$ & $15.95^{\mathrm{c}}$ & 0.113 & 26.08 \\
\hline $64 \mathrm{DTN}$ & $1.81^{\mathrm{ab}}$ & $159.1^{\mathrm{a}}$ & $17.21^{\mathrm{bc}}$ & 0.118 & 26.74 \\
\hline SW Makarfi 2006 & $1.54^{\mathrm{b}}$ & $135.4^{\mathrm{c}}$ & $22.28^{\mathrm{a}}$ & 0.118 & 31.04 \\
\hline SW Dansadau 2007 & $1.91^{\mathrm{a}}$ & $129.9^{c}$ & $19.81^{\mathrm{ab}}$ & 0.112 & 33.90 \\
\hline SED & 0.114 & 4.03 & 1.382 & 0.003 & 3.816 \\
\hline $\operatorname{LSD}_{(0.05)}$ & 0.278 & 9.86 & 3.381 & ns & ns \\
\hline \multicolumn{6}{|c|}{ Fertilizer (F) $\left(\mathrm{kgNha}^{-1}\right)$} \\
\hline 0 & $1.36^{\mathrm{c}}$ & 150.0 & $15.60^{\mathrm{d}}$ & 0.106 & $19.35^{\mathrm{c}}$ \\
\hline 40 & $2.00^{\mathrm{a}}$ & 142.5 & $21.28^{\mathrm{a}}$ & 0.121 & $36.79^{\mathrm{a}}$ \\
\hline 80 & $1.93^{\mathrm{ab}}$ & 142.5 & $18.48^{\mathrm{bc}}$ & 0.117 & $29.64^{b}$ \\
\hline 120 & $2.03^{\mathrm{a}}$ & 129.3 & $20.90^{\mathrm{ab}}$ & 0.115 & $35.92^{\mathrm{a}}$ \\
\hline 160 & $1.69^{\mathrm{b}}$ & 149.9 & $17.80^{\mathrm{cd}}$ & 0.116 & $25.49^{\mathrm{b}}$ \\
\hline SED & 0.131 & 9.28 & 1.282 & 0.0058 & 2.918 \\
\hline $\operatorname{LSD}_{(0.05)}$ & 0.266 & ns & 2.612 & ns & 5.943 \\
\hline \multicolumn{6}{|l|}{ Interaction } \\
\hline $\mathrm{V} \times \mathrm{F}$ & ns & ns & ns & ns & * \\
\hline
\end{tabular}

Means followed by the same letters are not significantly different from each other at $5 \%$ probability level. $\operatorname{LSD}_{(0.05)}$ : least significant difference at $5 \%$ probability level. SED: standard error of difference. * denotes significance at $5 \%$ probability level. ns: not significant.

Variations were observed in fresh stalk yield and average stalk length among the varieties, with the variety SW Dansadau 2007 having the highest values at both experimental sites (Table 4 ). The variety 64 DTN had the highest average stalk girth $(1.68 \mathrm{~cm})$ at both experimental sites, but no significant difference in the ASG values of the varieties was observed at the Ejiba site. The application of 80, 120, and $160 \mathrm{~kg} \mathrm{ha}^{-1}$ nitrogen fertilizer rates resulted in similar fresh stalk yield at both experimental sites. The longest stalks were obtained with the application of $40 \mathrm{~kg} \mathrm{Nha}^{-1}$ at both 
TABLE 4: Main effects of variety and $\mathrm{N}$ fertilizer on the fresh stalk yield (FSY, $\mathrm{tha}^{-1}$ ), average stalk length (ASL, $\mathrm{cm}$ ), and average stalk girth (ASG, $\mathrm{cm}$ ) of sweet sorghum at the Ilorin (ILR) and Ejiba (EJB) experimental sites.

\begin{tabular}{|c|c|c|c|c|c|c|}
\hline \multirow{2}{*}{ Treatment } & \multicolumn{2}{|c|}{ FSY } & \multicolumn{2}{|c|}{ ASL } & \multicolumn{2}{|c|}{ ASG } \\
\hline & ILR & EJB & ILR & EJB & ILR & EJB \\
\hline \multicolumn{7}{|l|}{$\overline{\operatorname{Variety}(V)}$} \\
\hline NTJ-2 & $20.09^{c}$ & $19.26^{\mathrm{b}}$ & $132.3^{\mathrm{c}}$ & $152.8^{\mathrm{b}}$ & $1.52^{\mathrm{b}}$ & 1.41 \\
\hline $64 \mathrm{DTN}$ & $25.32^{\mathrm{a}}$ & $19.49^{\mathrm{b}}$ & $125.1^{c}$ & $141.4^{\mathrm{b}}$ & $1.68^{\mathrm{a}}$ & 1.48 \\
\hline SW Makarfi 2006 & $22.59^{\mathrm{b}}$ & $18.18^{\mathrm{b}}$ & $148.1^{\mathrm{b}}$ & $146.5^{\mathrm{b}}$ & $1.51^{\mathrm{b}}$ & 1.36 \\
\hline SW Dansadau 2007 & $27.75^{\mathrm{a}}$ & $25.21^{\mathrm{a}}$ & $166.3^{\mathrm{a}}$ & $182.3^{\mathrm{a}}$ & $1.48^{\mathrm{b}}$ & 1.42 \\
\hline SED & 1.02 & 1.11 & 3.05 & 4.65 & 2.24 & 0.038 \\
\hline $\operatorname{LSD}_{(0.05)}$ & 2.49 & 2.72 & 7.46 & 11.39 & 5.49 & ns \\
\hline \multicolumn{7}{|c|}{ Fertilizer (F) $\left(\mathrm{kg} \mathrm{Nha}^{-1}\right)$} \\
\hline 0 & $15.43^{\mathrm{c}}$ & $16.45^{\mathrm{b}}$ & $130.9^{c}$ & $143.4^{\mathrm{c}}$ & $1.31^{\mathrm{d}}$ & $1.29^{\mathrm{b}}$ \\
\hline 40 & $23.69^{\mathrm{b}}$ & $22.69^{\mathrm{a}}$ & $151.0^{\mathrm{a}}$ & $167.4^{\mathrm{a}}$ & $1.56^{\mathrm{bc}}$ & $1.45^{\mathrm{a}}$ \\
\hline 80 & $27.41^{\mathrm{a}}$ & $20.85^{\mathrm{a}}$ & $143.8^{\mathrm{ab}}$ & $152.5^{\mathrm{bc}}$ & $1.50^{\mathrm{c}}$ & $1.45^{\mathrm{a}}$ \\
\hline 120 & $27.22^{\mathrm{a}}$ & $21.91^{\mathrm{a}}$ & $139.8^{\mathrm{b}}$ & $160.4^{\mathrm{ab}}$ & $1.75^{\mathrm{a}}$ & $1.47^{\mathrm{a}}$ \\
\hline 160 & $25.95^{\mathrm{a}}$ & $20.78^{\mathrm{a}}$ & $149.1^{\mathrm{a}}$ & $155.0^{\mathrm{b}}$ & $1.62^{\mathrm{b}}$ & $1.44^{\mathrm{a}}$ \\
\hline SED & 0.79 & 1.67 & 3.85 & 4.50 & 4.24 & 4.63 \\
\hline $\operatorname{LSD}_{(0.05)}$ & 1.61 & 3.39 & 7.83 & 9.16 & 8.63 & 9.43 \\
\hline \multicolumn{7}{|l|}{ Interaction } \\
\hline $\mathrm{V} \times \mathrm{F}$ & $* *$ & $*$ & ns & $* *$ & ns & ns \\
\hline
\end{tabular}

Means followed by the same letters are not significantly different from each other at $5 \%$ probability level. $\operatorname{LSD}_{(0.05)}$ : least significant difference at $5 \%$ probability level. SED: standard error of difference. $*$ and $* *$ denote significance at $5 \%$ and $1 \%$ probability levels, respectively. ns: not significant.

TABLE 5: Main effects of variety and N fertilizer on the brix (\%), juice yield (JY, tha ${ }^{-1}$ ), and ethanol yield (EY, L ha ${ }^{-1}$ ) of sweet sorghum at the Ilorin (ILR) and Ejiba (EJB) experimental sites.

\begin{tabular}{|c|c|c|c|c|c|c|}
\hline \multirow{2}{*}{ Treatment } & \multicolumn{2}{|c|}{ Brix } & \multicolumn{2}{|c|}{ JY } & \multicolumn{2}{|c|}{ EY } \\
\hline & ILR & EJB & ILR & EJB & ILR & EJB \\
\hline \multicolumn{7}{|l|}{ Variety $(V)$} \\
\hline NTJ-2 & $12.0^{\mathrm{d}}$ & $15.0^{\mathrm{a}}$ & $12.92^{\mathrm{d}}$ & $12.20^{\mathrm{b}}$ & $689.6^{c}$ & $802.8^{\mathrm{a}}$ \\
\hline $64 \mathrm{DTN}$ & $13.0^{\mathrm{c}}$ & $15.6^{\mathrm{a}}$ & $16.06^{\mathrm{b}}$ & $12.57^{\mathrm{b}}$ & $940.3^{\mathrm{b}}$ & $866.1^{\mathrm{a}}$ \\
\hline SW Makarfi 2006 & $13.5^{\mathrm{b}}$ & $12.3^{\mathrm{b}}$ & $14.54^{\mathrm{c}}$ & $12.21^{\mathrm{b}}$ & $872.4^{\mathrm{b}}$ & $656.8^{\mathrm{b}}$ \\
\hline SW Dansadau 2007 & $15.5^{\mathrm{a}}$ & $12.2^{\mathrm{b}}$ & $17.49^{\mathrm{a}}$ & $16.42^{\mathrm{a}}$ & $1197.5^{\mathrm{a}}$ & $885.5^{\mathrm{a}}$ \\
\hline SED & 0.15 & 0.39 & 0.56 & 0.69 & 41.15 & 43.90 \\
\hline $\operatorname{LSD}_{(0.05)}$ & 0.36 & 0.96 & 1.37 & 1.69 & 100.69 & 107.42 \\
\hline \multicolumn{7}{|c|}{ Fertilizer $(F)\left(\mathrm{kgNha}^{-1}\right)$} \\
\hline 0 & $10.9^{\mathrm{d}}$ & $11.4^{\mathrm{c}}$ & $9.76^{\mathrm{d}}$ & $10.27^{\mathrm{b}}$ & $465.3^{\mathrm{d}}$ & $508.5^{\mathrm{b}}$ \\
\hline 40 & $12.5^{\mathrm{c}}$ & $13.9^{\mathrm{b}}$ & $14.90^{c}$ & $14.58^{\mathrm{a}}$ & $829.1^{c}$ & $870.8^{\mathrm{a}}$ \\
\hline 80 & $14.6^{\mathrm{b}}$ & $14.3^{\mathrm{b}}$ & $17.24^{\mathrm{ab}}$ & $13.76^{\mathrm{a}}$ & $1114.4^{\mathrm{a}}$ & $863.8^{\mathrm{a}}$ \\
\hline 120 & $15.1^{\mathrm{a}}$ & $15.1^{\mathrm{a}}$ & $17.72^{\mathrm{a}}$ & $14.33^{\mathrm{a}}$ & $1183.9^{\mathrm{a}}$ & $930.5^{\mathrm{a}}$ \\
\hline 160 & $14.4^{\mathrm{b}}$ & $14.1^{\mathrm{b}}$ & $16.64^{b}$ & $13.82^{\mathrm{a}}$ & $1032.0^{\mathrm{b}}$ & 840.4 \\
\hline SED & 0.24 & 0.22 & 0.50 & 1.07 & 35.84 & 71.08 \\
\hline $\operatorname{LSD}_{(0.05)}$ & 0.49 & 0.45 & 1.01 & 2.18 & 73.00 & 144.79 \\
\hline \multicolumn{7}{|l|}{ Interaction } \\
\hline $\mathrm{V} \times \mathrm{F}$ & $* *$ & $* *$ & $* *$ & $*$ & $* *$ & $*$ \\
\hline
\end{tabular}

Means followed by the same letters are not significantly different from each other at $5 \%$ probability level. $\mathrm{LSD}_{(0.05)}$ : least significant difference at $5 \%$ probability level. SED: standard error of difference. $*$ and $* *$ denote significance at $5 \%$ and $1 \%$ probability levels, respectively. ns: not significant.

sites while the application rate of $120 \mathrm{~kg} \mathrm{ha}^{-1}$ resulted in the thickest stalks at both sites (Table 4). Although no clearcut trend could be identified with respect to the effects of nitrogen fertilizer in these parameters, nitrogen fertilizer application significantly improved the performance of the crop over control. This is as a result of the sum total of the effects of $\mathrm{N}$ fertilizer on the growth of the crop.

Table 5 reveals that, apart from brix at the Ejiba site, the variety SW Dansadau 2007 had the highest brix, juice yield, and ethanol yield values at the two experimental sites. The 
table also shows that the application of $120 \mathrm{~kg} \mathrm{~N} \mathrm{ha}^{-1}$ resulted in the highest values in these parameters except juice yield at the Ejiba site. The value of ethanol yield is a direct result of brix value and the juice yield, which also correlates with the fresh stalk yield of the crop [22]. High ethanol yield can be obtained, as demonstrated by this study, by nitrogen application and by breeding for sweet sorghum strains with long and thick stalks without compromising juice quality such as brix.

\section{Conclusion}

The outcome of this study shows that application of nitrogen fertilizer enhanced the growth and ethanol yield of sweet sorghum compared with the control. Variations in terms of growth and ethanol yield were also observed among the four varieties studied, with the variety SW Dansadau 2007 having the best performance, especially in ethanol yield. The application of $120 \mathrm{~kg} \mathrm{~N} \mathrm{ha}^{-1}$ resulted in the best growth response and ethanol yield. The study however also revealed that the fertilizer rate of as low as $40 \mathrm{~kg} \mathrm{Nha}^{-1}$ would also result in reasonable performance of the crop in the areas of this study, especially under favourable environmental conditions.

\section{Competing Interests}

The authors declare that they have no competing interests.

\section{References}

[1] R. P. Parthasarathy and M. C. S. Bantilan, Emerging Biofuel Industry: A Case Study for Pro-poor Agenda with Special Reference to India, GT IMPI Policy Brief no. 12, International Crops Research Institute for Semi-Arid Tropics (ICRISAT), Patancheru, India, 2007.

[2] M. Balat and H. Balat, "Recent trends in global production and utilization of bio-ethanol fuel," Applied Energy, vol. 86, no. 11, pp. 2273-2282, 2009.

[3] S. Zafar, "Importance of biomass energy", 2014, http://www .bioenergyconsult.com/tag/importance-of-biomass-energy/.

[4] P. S. Rao, S. S. Rao, N. Seetharama et al., "Sweet sorghum for biofuel and strategies for its improvement," Information Bulletin 77, International Crops Research Institute for the SemiArid Tropics, Patancheru, India, 2009.

[5] R. A. Sami, M. Y. Yeye, I. S. Usman, L. B. Hassan, and M. Usman, "Studies on genetic variability in some sweet sorghum (Sorghum bicolor L. Moench.) genotypes," Academic Research Journal of Agricultural Science and Research, vol. 1, no. 1, pp. 1-6, 2013.

[6] B. Reddy, S. Ramesh, P. S. Reddy et al., Sweet Sorghum: Food, Feed, Fodder and Fuel Crop, International Crops Research Institute for the Semi-Arid Tropics (ICRISAT), Patancheru, India, 2007.

[7] P. S. Rao, C. G. Kumar, and B. V. Reddy, "Sweet sorghum: from theory to practice," in Characterization of Improved Sweet Sorghum Cultivars, P. S. Rao and C. G. Kumar, Eds., SpringerBriefs in Agriculture, pp. 1-15, Springer, New Delhi, India, 2013.

[8] M. A. Sanderson, R. M. Jones, J. Ward, and R. Wolfe, "Silage sorghum performance trial at Stephenville," Forage Research in
Texas. Report PR-5018, Texas Agricultural Experiment Station, Stephenville, Tex, USA, 1992.

[9] C. S. Wortmann, A. J. Liska, R. B. Ferguson, D. J. Lyon, R. N. Klein, and I. Dweikat, "Dryland performance of sweet sorghum and grain crops for biofuel in Nebraska," Agronomy Journal, vol. 102, no. 1, pp. 319-326, 2010.

[10] J. M. Soileau and B. N. Bradford, "Biomass and sugar yield response of sweet sorghum to lime and fertilizer," Agronomy Journal, vol. 77, pp. 471-475, 1985.

[11] B. V. S. Reddy, S. Ramesh, S. P. Reddy, B. Ramaiah, P. M. Salimath, and K. Rajashekar, "Sweet sorghum-a potential alternative raw material for bio-ethanol and bio-energy," International Sorghum and Millets Newsletter, vol. 46, pp. 79-86, 2005.

[12] I. Turgut, U. Bilgili, A. Duman, and E. Acikgoz, "Production of sweet sorghum (Sorghum bicolor L. Moench) increases with increased plant densities and nitrogen fertilizer levels," Acta Agriculturae Scandinavica Section B: Soil \& Plant Science, vol. 55, no. 3, pp. 236-240, 2005.

[13] H. Uchino, T. Watanabe, K. Ramu et al., "Effects of nitrogen application on sweet sorghum (Sorghum bicolor (L.) Moench) in the semi-arid tropical zone of India," Japan Agricultural Research Quarterly, vol. 47, no. 1, pp. 65-73, 2013.

[14] F. C. Stickler, S. Wearden, and A. W. Pauli, "Leaf area determination in grain sorghum," Agronomy Journal, vol. 53, no. 3, pp. 187-188, 1961.

[15] R. H. Moll and E. J. Kamprath, "Effect of population density upon agronomic traits associated with generic increases in yield of Zea mays L.," Agronomy Journal, vol. 96, pp. 81-84, 1977.

[16] R. Hunt, "Plant growth analysis studies: the rationale behind the use of the fitted function," Annals of Botany, vol. 43, pp. 245-249, 1978.

[17] T. L. Tew, R. M. Cobill, and E. P. Richard Jr., "Evaluation of sweet sorghum and sorghum $\times$ sudangrass hybrids as feedstocks for ethanol production," BioEnergy Research, vol. 1, no. 2, pp. 147$152,2008$.

[18] A. J. Liska, H. S. Yang, V. R. Bremer et al., "Improvements in life cycle energy efficiency and greenhouse gas emissions of cornethanol," Journal of Industrial Ecology, vol. 13, no. 1, pp. 58-74, 2009.

[19] P. L. Tamang, K. F. Bronson, A. Malapati, R. Schwartz, J. Johnson, and J. Moore-Kucera, "Nitrogen requirements for ethanol production from sweet and photoperiod sensitive sorghums in the southern high plains," Agronomy Journal, vol. 103, no. 2, pp. 431-440, 2011.

[20] V. H. Teetor, D. V. Duclos, E. T. Wittenberg et al., "Effects of planting date on sugar and ethanol yield of sweet sorghum grown in Arizona," Industrial Crops and Products, vol. 34, no. 2, pp. 1293-1300, 2011.

[21] C. W. Smith and R. A. Frederiksen, Sorghum: Origin, History, Technology, and Production, John Wiley and Sons, New York, NY, USA, 2000.

[22] A. Almodares, M. R. Hadi, and H. Ahmadpour, "Sorghum stem yield and soluble carbohydrates under different salinity levels," African Journal of Biotechnology, vol. 7, no. 22, pp. 4051-4055, 2008.

[23] G. A. M. S. Agung, K. Sardiana, W. Diara, and G. M. O. Nurjaya, "Adaptations, biomass and ethanol yields of sweet sorghum (Sorghum bicolor (L.) Moench) varieties at dryland farming areas of Jimbaran Bali, Indonesia," Journal of Biology, Agriculture and Healthcare, vol. 3, no. 17, pp. 111-115, 2013. 
[24] C. G. Kumar and P. S. Rao, "Methodology, results and discussion," in Characterization of Improved Sweet Sorghum Cultivars, P. S. Rao and C. G. Kumar, Eds., SpringerBriefs in Agriculture, pp. 17-30, 2013.

[25] G. L. Sawargaonkar, M. D. Patil, S. P. Wani, E. Pavani, B. V. S. R. Reddy, and S. Marimuthu, "Nitrogen response and water use efficiency of sweet sorghum cultivars," Field Crops Research, vol. 149, pp. 245-251, 2013.

[26] S. P. Singh, Y. P. Joshi, R. K. Singh, and V. S. Meena, "Influence of nitrogen levels and seed rate on growth, yield and quality of sweet sorghum," Annals of Biology, vol. 30, no. 1, pp. 89-93, 2014.

[27] Y. A. Abayomi and O. Fagbenja, "Morpho-physiological basis for yield variation in varieties of maize at different levels of fertilizer applications," Journal of Agricultural Research and Development, vol. 4, pp. 32-57, 2005. 


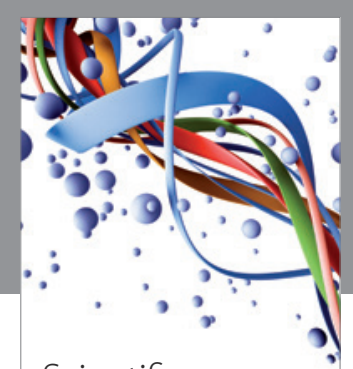

Scientifica
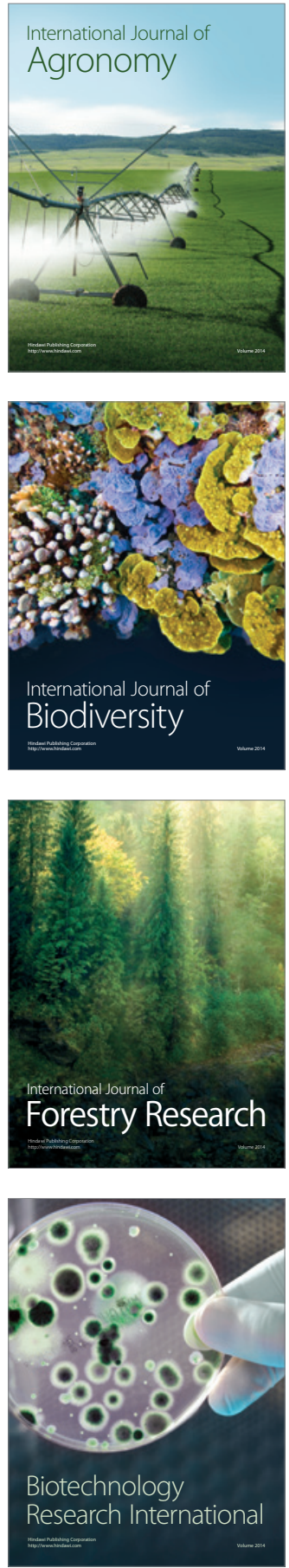
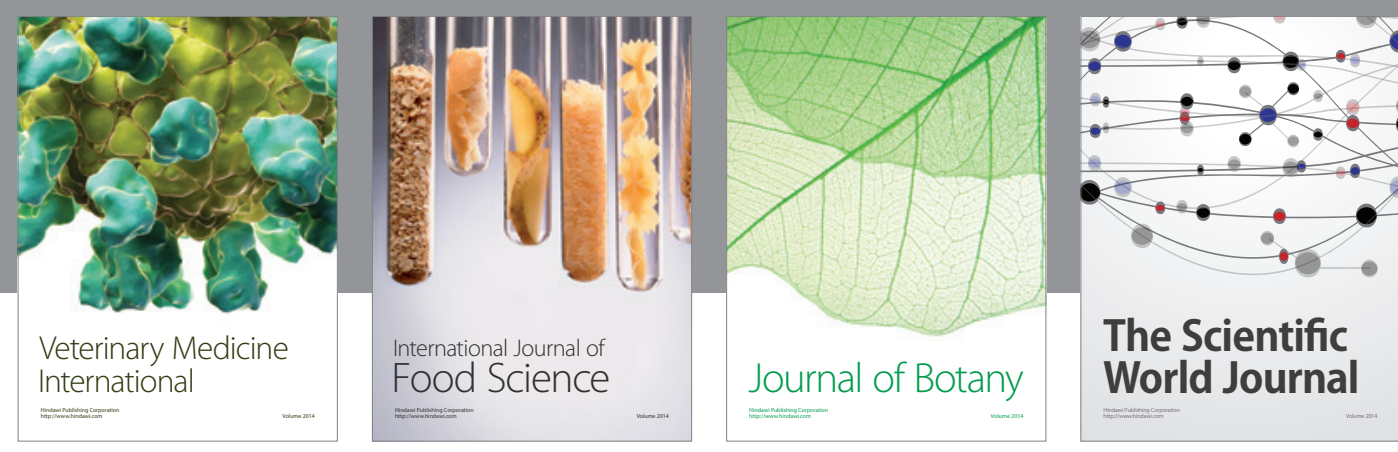

The Scientific

\section{World Journal}

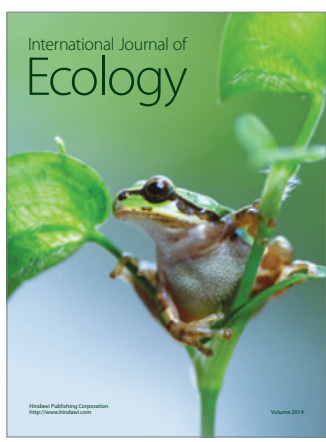

\section{Hindawi}

Submit your manuscripts at

http://www.hindawi.com
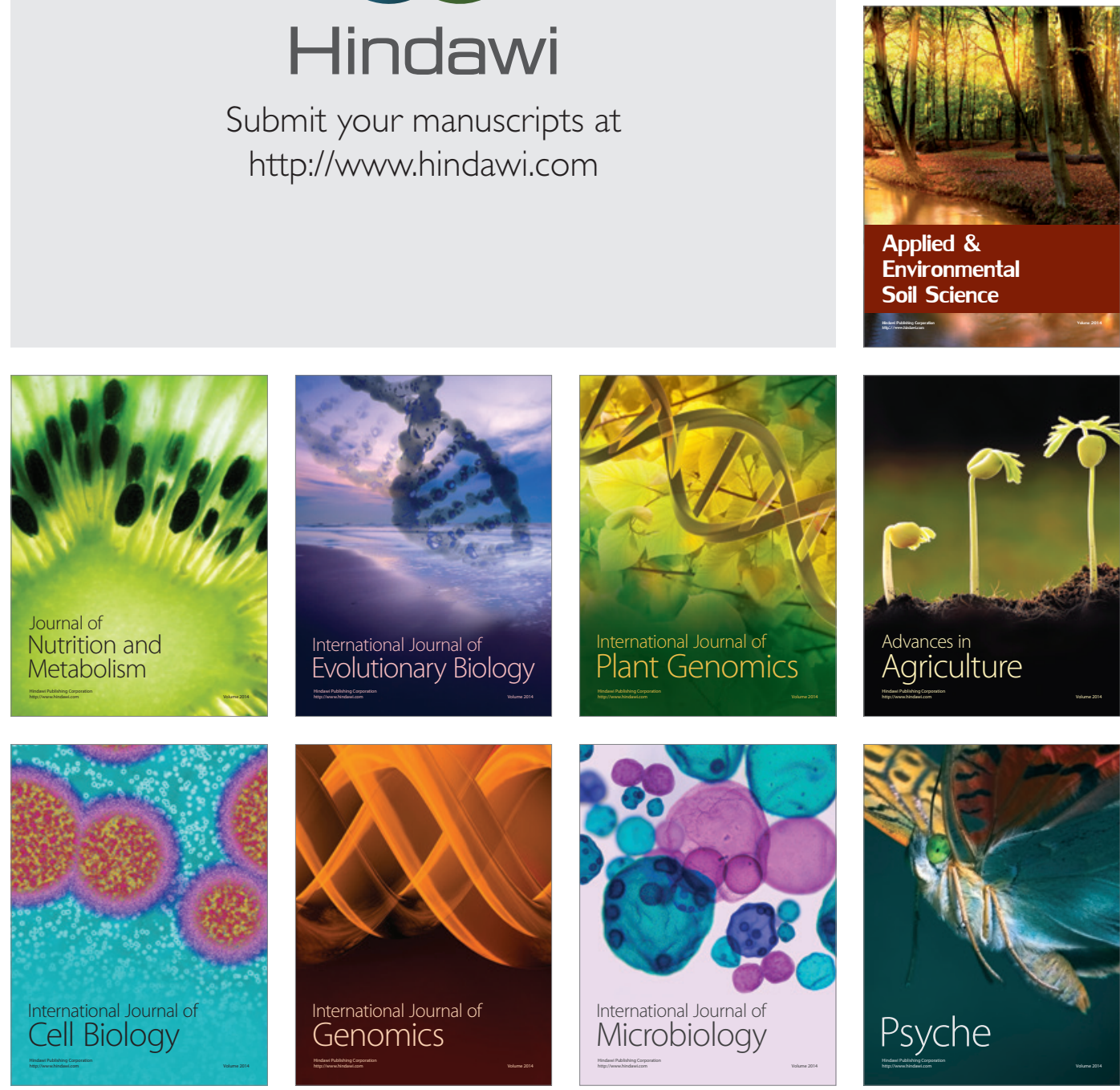
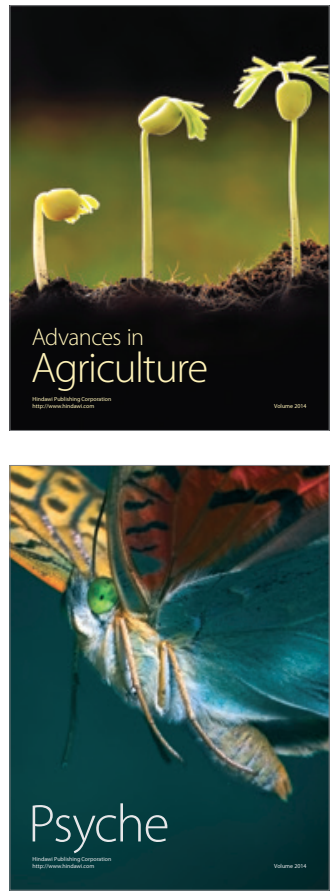